\title{
Dipeptidyl peptidase IV resistant analogues of glucagon-like peptide-1 which have extended metabolic stability and improved biological activity
}

\author{
C. F. Deacon ${ }^{1}$, L. B. Knudsen ${ }^{2}$, K. Madsen ${ }^{2}$, F. C. Wiberg ${ }^{2}$, O. Jacobsen ${ }^{1}$, J.J.Holst ${ }^{1}$ \\ ${ }^{1}$ Department of Medical Physiology, The Panum Institute, University of Copenhagen, Denmark \\ ${ }^{2}$ Novo Nordisk A/S, Måløv, Denmark
}

\begin{abstract}
Summary Glucagon-like peptide 1 (GLP-1) has great potential in diabetes therapy due to its glucose-dependent stimulation of insulin secretion, but this is limited by its rapid degradation, primarily by dipeptidyl peptidase IV. Four analogues, N-terminally substituted with threonine, glycine, serine or $\alpha$-aminoisobutyric acid, were synthesised and tested for metabolic stability. All were more resistant to dipeptidyl peptidase IV in porcine plasma in vitro, ranging from a $\mathrm{t}_{1 / 2}$ of $159 \mathrm{~min}\left(\mathrm{Gly}^{8}\right.$ analogue $)$ to undetectable degradation after $6 \mathrm{~h}$ ( Aib $^{8}$ analogue; $t_{1 / 2}$ for GLP-1 (7-36) amide, $28 \mathrm{~min}$ ). During i.v. infusion in anaesthetised pigs, over $50 \%$ of each analogue remained undegraded compared to $22.7 \%$ for GLP-1 (736) amide. In vivo, analogues had longer N-terminal $\mathrm{t}_{1 / 2}$ (intact peptides: means, 3.3-3.9 min) than GLP-1 (7-36) amide ( $0.9 \mathrm{~min} ; p<0.01)$, but these did not exceed the $\mathrm{C}$-terminal $\mathrm{t}_{1 / 2}$ (intact plus metabolite: analogues, 3.5-4.4 min; GLP-1 (7-36) amide, $4.1 \mathrm{~min}$ ). Analogues were assessed for receptor binding using
\end{abstract}

a cell line expressing the cloned receptor, and for ability to stimulate insulin or inhibit glucagon secretion from the isolated perfused porcine pancreas. All bound to the receptor, but only the $\mathrm{Aib}^{8}$ and Gly ${ }^{8}$ analogues had similar affinities to GLP-1 (7-36) amide $\left(\mathrm{IC}_{50} ; \mathrm{Aib}^{8}=0.45 \mathrm{nmol} / \mathrm{l} ; \mathrm{Gly}^{8}=2.8 \mathrm{nmol} / \mathrm{l} ; \mathrm{GLP}-1\right.$ (7-36) amide $=0.78 \mathrm{nmol} / \mathrm{l})$. All analogues were active in the isolated pancreas, with the potency order reflecting receptor affinities $\left(\mathrm{Aib}^{8}>\mathrm{Gly}^{8}>\right.$ $\mathrm{Ser}^{8}>\mathrm{Thr}^{8}$ ). N-terminal modification of GLP-1 confers resistance to dipeptidyl peptidase IV degradation. Such analogues are biologically active and have prolonged metabolic stability in vivo, which, if associated with greater potency and duration of action, may help to realise the potential of GLP-1 in diabetes therapy. [Diabetologia (1998) 41: 271-278]

Keywords Glucagon-like peptide-1, analogue, dipeptidyl peptidase IV, non-insulin-dependent diabetes mellitus, therapy.
The insulinotropic hormone glucagon-like peptide-1 (GLP-1) is the product of tissue-specific post-translational processing of the glucagon precursor, progluca-

Received: 9 September 1997 and in revised form: 20 October 1997

Corresponding author: Dr. C.F.Deacon, Department of Medical Physiology, The Panum Institute, Blegdamsvej 3, DK-2200 Copenhagen N, Denmark

Abbreviations: GLP-1, Glucagon-like peptide-1; DPP IV, dipeptidyl peptidase IV; PG, proglucagon; GRF, growth hormone-releasing factor; TFA, trifluoroacetic acid; ANOVA, analysis of variance; NIDDM, non-insulin-dependent diabetes mellitus; Aib, $\alpha$-aminoisobutyric acid; HSA, human serum albumin; BHK, baby hamster kidney. gon (PG) in the L-cells of the gastrointestinal mucosa $[1,2]$. This results in the formation of GLP-1 (736) amide (corresponding to PG (78-107) amide), which is the predominant form in humans, although small amounts of non-amidated glycine-extended GLP-1 (7-37) are also produced [3]. GLP-1 is one of the most potent insulin secretagogues identified [4] and this, together with the glucose-dependency of its actions [5-7], has focussed interest on its role as a regulator of blood glucose and its potential as a therapeutic agent in the treatment of non-insulin-dependent diabetes mellitus (NIDDM) [6, 8-11].

Recent studies have shown that GLP-1 itself is the subject of further enzyme cleavage. In particular, dipeptidyl peptidase IV (DPP IV; EC 3.4.14.5) is im- 
portant, resulting in a metabolite which is N-terminally truncated by 2 amino acids [12-14]. The resulting peptide, GLP-1 (9-36) amide, is an endogenous metabolite [13] which is an antagonist in vitro [15, 16]. Moreover, exogenously administered GLP-1 is also rapidly degraded in both diabetic and non-diabetic subjects, with GLP-1 (9-36) amide being the major metabolite [17]. In a strain of rats lacking DPP IV, this metabolite is not formed [14]. DPP IV is highly specific and has strict substrate requirements $[18,19]$, raising the possibility of developing analogues which the enzyme is unable to cleave. Studies with another peptide substrate of DPP IV, growth hormone-releasing factor (GRF), have shown that analogues with $\mathrm{N}$-terminal amino acid substitutions have some resistance to the enzyme's action [20]. The present study was undertaken to examine whether small modifications of the N-terminus of GLP-1 would also confer resistance to degradation by DPP IV, while retaining the peptide's biological activity.

\section{Materials and methods}

Peptide synthesis. Peptides were synthesised on an Applied Biosystems 431A peptide synthesiser (Foster City, Calif., USA), according to the Fmoc strategy, using the following protected amino acid derivatives: Fmoc-Arg $(\mathrm{Pmc})$, FmocTrp(Boc), Fmoc-Glu(OBut), Fmoc-Lys(Boc), Fmoc-Gln(Trt), Fmoc-Tyr(But), Fmoc-Ser(But), Fmoc-Thr(But), FmocHis(Trt) and Fmoc-Asp(OBut) (Calbiochem-Novabiochem AG, Läufelingen, Switzerland). The peptides were deprotected and cleaved from the resin by treatment with trifluoroacetic acid (TFA)/phenol/thioanisole/water/ethanedithiol (83.25:6.25:4.25:2.00) for $180 \mathrm{~min}$. After evaporation of the TFA, the crude peptide was precipitated with diethyl ether and purified by semipreparative HPLC on a $\mathrm{C}_{18}$ reversedphase column eluted with a gradient of acetonitrile in $0.05 \mathrm{~mol} / \mathrm{l}\left(\mathrm{NH}_{4}\right)_{2} \mathrm{SO}_{4}, \mathrm{pH} 2.5$. Peptide-containing fractions were applied to a Sep Pak $\mathrm{C}_{18}$ cartridge (Waters-Millipore, Milford, Mass., USA), eluted with $70 \%$ acetonitrile/ $0.1 \%$ TFA and lyophilised. The final products were characterised by amino acid analysis, analytical reversed-phase HPLC and by plasma desorption mass spectrometry. Purity was more than $95 \%$ by HPLC with detection at $214 \mathrm{~nm}$. Analogues, substituted at position 8 of GLP-1 with either threonine (Thr ${ }^{8}$-GLP-1 (737)), glycine (Gly ${ }^{8}$-GLP-1 (7-37)), serine (Ser ${ }^{8}$-GLP-1 (736) amide) or $\alpha$-aminoisobutyric acid ( $\mathrm{Aib}^{8}$-GLP-1 (736) amide and Aib ${ }^{8}$-GLP-1 (7-37)) were prepared.

Peptide stability in porcine plasma in vitro. The stability of each peptide in porcine plasma was determined by incubation at $37^{\circ} \mathrm{C}$ with $300 \mathrm{pmol} / \mathrm{l}$ of GLP-1 (7-36) amide or each analogue for up to $6 \mathrm{~h}$. This was followed by reversed-phase HPLC and RIA according to a previously published method [13], using antiserum 2135 as described below.

Peptide pharmacokinetics in vivo. Danish LYY strain pigs (33$40 \mathrm{~kg}$ ) were used. Food was withdrawn $24 \mathrm{~h}$ before surgery, but animals had free access to drinking water. After premedication with ketamine chloride (Ketaminol, $10 \mathrm{mg} / \mathrm{kg}$; Veterinaria AG, Zurich, Switzerland), animals were anaesthetised with $1 \%$ halothane (Halocarbon Laboratories, River Edge, NJ, USA), and anaesthesia was maintained with intermittent positive pressure ventilation using an anaesthesia ventilator in a semi-open system. Catheters were placed in the right carotid artery for sampling of arterial blood, and into a vein of the left ear for peptide infusion. After surgical preparation, animals were heparinised, an infusion $(0.9 \% \mathrm{NaCl})$ was set up and given via the ear vein catheter $(5 \mathrm{ml} / \mathrm{min})$, and the animals were left undisturbed for $30 \mathrm{~min}$.

Four groups of four animals were used. Each group received separate i.v. infusions of GLP-1 (7-36) amide and one analogue in a cross-over design with $80 \mathrm{~min}$ between each infusion. Synthetic GLP-1 (7-36) amide or analogues were dissolved in saline containing $1 \%$ human serum albumin (HSA; Behringwerke, Marburg, Germany), and infused at a rate of $5 \mathrm{pmol} \cdot \mathrm{kg}^{-1} \cdot \mathrm{min}^{-1}$ for $30 \mathrm{~min}$ using a syringe pump. Arterial blood samples $(4 \mathrm{ml})$ were taken at $0,5,10,15,20,22,25,27$ and $30 \mathrm{~min}$ from the start of the infusion. After $30 \mathrm{~min}$, the infusion was stopped, and further blood samples were taken at $1,2,4,6,10,15,20,30,40,50$ and $65 \mathrm{~min}$. The amount of blood taken over the entire procedure was $160 \mathrm{ml}$, which, for a $40 \mathrm{~kg}$ pig, is equivalent to $4 \%$ of the total blood volume.

Blood samples were collected into chilled tubes containing EDTA ( $7.4 \mathrm{mmol} / \mathrm{l}$ final concentration; Merck, Darmstadt, Germany), aprotinin (500 kallikrein inhibitory equivalents/ml blood; Novo Nordisk, Bagsværd, Denmark) and diprotin A ( $0.1 \mathrm{mmol} / 1$ final concentration; Bachem, Bubendorf, Switzerland), and kept on ice until centrifugation at $4^{\circ} \mathrm{C}$. Plasma was separated and stored at $-20^{\circ} \mathrm{C}$ until analysis with the RIAs described below. In addition, plasma collected during mins 22-30 of each infusion was separately pooled for each group of four animals, extracted on Sep Pak $\mathrm{C}_{18}$ cartridges and analysed by reversed-phase HPLC and RIA as before [13], using antiserum 2135, described below.

Expression of the cloned human GLP-1 receptor. The human GLP-1 receptor cDNA was obtained from Dr. B. Thorens. The cDNA was subcloned into the pcDNA 1 vector (Invitrogen Corporation, San Diego, Calif., USA) using the Hind III - EcoRI sites, and was then called pAH 260. Baby hamster kidney (BHK) cells were co-transfected with $20 \mu \mathrm{g}$ pAH 260 and $0.6 \mu \mathrm{g}$ pSV 2 neo vector [21] using the methods described by Chen and Okayama [22], and grown in Dulbecco's modified Eagle's medium, $10 \%$ fetal calf serum, 100 IU penicillin, $100 \mu \mathrm{g} / \mathrm{ml}$ streptomycin and $1 \mathrm{mmol} / \mathrm{l} \mathrm{Na}$-pyruvate (all from Gibco, Life Technologies, Roskilde, Denmark). Stable clones were selected in medium containing $1 \mathrm{mg} / \mathrm{ml}$ Geneticin G-418 (Gibco) and maintained at $37^{\circ} \mathrm{C}$, in an atmosphere containing $5 \% \mathrm{CO}_{2}$. Stable clones were screened in a receptor binding assay, and those expressing high levels of GLP-1 receptor were then recloned and screened in an adenylate cyclase assay to find clones with functional receptors. These clones were selected for further studies.

Receptor binding. Receptor binding was carried out as previously described [16], using BHK cells expressing the human pancreatic GLP-1 receptor. In brief, plasma membranes were prepared by homogenisation with two $10 \mathrm{~s}$ bursts using a Polytron PT 10-35 homogeniser (Kinematica, Lucerne, Switzerland), in a buffer consisting of $10 \mathrm{mmol} / \mathrm{l}$ Tris- $\mathrm{HCl}$ with $30 \mathrm{mmol} / 1 \mathrm{NaCl}, \mathrm{pH} 7.4$, containing in addition, $1 \mathrm{mmol} / 1$ dithiothreitol, $5 \mathrm{mg} / \mathrm{l}$ leupeptin, $5 \mathrm{mg} / \mathrm{l}$ pepstatin, $100 \mathrm{mg} / \mathrm{l}$ bacitracin (all from Sigma, St. Louis, Mo, USA) and $16 \mathrm{mg} / \mathrm{l}$ aprotinin, and centrifuged on top of a layer of $41 \%$ (wt/vol) sucrose at $95000 \times g$ for $75 \mathrm{~min}$. The white band between the two layers was diluted in buffer and centrifuged at $40000 \times g$ for $45 \mathrm{~min}$. The precipitate containing the plasma membranes was suspended in buffer, and stored at $-80^{\circ} \mathrm{C}$ until use. 
The binding assay was performed in 96-well filter microtitre plates. The buffer used was $50 \mathrm{mmol} / \mathrm{l} \mathrm{HEPES,} \mathrm{pH} 7.4$, with the addition of $2.5 \%$ (wt/vol) HSA grade V (Sigma). Peptide, tracer and plasma membranes were incubated for $30 \mathrm{~min}$ at $30^{\circ} \mathrm{C}$. The tracer was prepared by iodination of GLP-1 (7-36) amide using the lactoperoxidase method [23]. Purification by HPLC as previously described [24] yielded ${ }^{125} \mathrm{I}_{-\mathrm{Tyr}}{ }^{19}$-GLP-1 (736) amide with a specific activity of $80 \mathrm{kBq} / \mathrm{pmol}$.

Isolated perfused pancreas. Danish LYY strain pigs (14$16 \mathrm{~kg}$ ) were fasted overnight and anaesthetised with chloralose $(100 \mathrm{mg} / \mathrm{kg}$; Merck). The pancreases were isolated as previously described [25] and perfused in a single-pass system, using a gassed $\left(5 \% \mathrm{CO}_{2}\right.$ in $\left.\mathrm{O}_{2}\right)$ Krebs-Ringer-bicarbonate perfusion medium containing, in addition, $0.1 \%$ HSA, $5 \%$ dextran T 70 (Pharmacia, Uppsala, Sweden) and $5 \mathrm{mmol} / \mathrm{l}$ glucose. The venous effluent was collected for 1-min intervals, centrifuged at $4{ }^{\circ} \mathrm{C}$, and stored at $-20^{\circ} \mathrm{C}$ until analysis. Synthetic GLP-1 (7-36)amide or peptide analogues were dissolved in $0.04 \mathrm{~mol} / \mathrm{l}$ phosphate buffer, $\mathrm{pH} 7.4$, containing $1 \%$ HSA, and infused into the arterial line using a syringe pump, to give final concentrations of $1 \mathrm{nmol} / \mathrm{l}$ in the perfusate. Peptides were infused for $10 \mathrm{~min}$ periods, separated by 10 15 min rest periods, during which time endocrine secretion returned to basal levels. Insulin and glucagon concentrations in the venous effluent were measured by RIA as described below.

Hormonal analysis. HPLC fractions were analysed using antiserum 2135 [26, 27], which is "side-viewing", and which recognises all molecules containing the central sequence of GLP-1 regardless of C- or N-terminal truncations or extensions. It cross-reacts fully with GLP-1 (7-37), 79\% with GLP-1 (9-36) amide, and has a detection limit of $5 \mathrm{pmol} / \mathrm{l}$. Plasma samples were assayed for GLP-1 immunoreactivity using RIAs which are specific for each terminus of the molecule. N-terminal immunoreactivity was measured using the newly described antiserum 93242 [28], which has a cross-reactivity of approximately $10 \%$ with GLP-1 (1-36) amide, and less than $0.1 \%$ with GLP-1 (8-36) amide and GLP-1 (936) amide, and has a detection limit of 5 pmol/l. C-terminal immunoreactivity was measured using antiserum 89390 or 92071 as appropriate. Antiserum $89390[3,29]$ has an absolute requirement for the intact amidated C-terminus of GLP-1 (7-36) amide, and cross-reacts less than $0.01 \%$ with C-terminally truncated fragments, and $83 \%$ with GLP-1 (936) amide. The detection limit is $1 \mathrm{pmol} / \mathrm{l}$. Antiserum 92071 [3] is specific for the C-terminus of GLP-1 (7-37) and crossreacts less than $0.1 \%$ with GLP-1 (7-36) amide. It has a detection limit of $4 \mathrm{pmol} / \mathrm{l}$. For all assays, the intra-assay coefficient of variation was less than $6 \%$. GLP-1 (7-36) amide, GLP-1 (7-37) or appropriate analogue were used as standard, and ${ }^{125}$ I-labelled GLP-1 (7-36) amide or GLP-1 (7-37) were used as tracer. Separation of antibody-bound from free peptide was achieved using plasma-coated charcoal [26, 29]. Plasma samples were extracted with $70 \%$ ethanol (vol/vol, final concentration) before assay, giving recoveries of $75 \%$ [27]. The cross-reactivity of each analogue was determined for each antiserum.

Venous effluent from the perfused pancreas was assayed using antiserum 2004 for insulin [27], and antiserum 4305 for glucagon [30].

Calculations. During the peptide infusions, stable arterial peptide levels were achieved after $20 \mathrm{~min}$, so the plateau concentration was defined as the mean of the last four measurements during the infusion. The plasma $t_{1 / 2}$ was calculated by ln-linear regression analysis of peptide concentrations in samples collected after termination of the infusion, after subtraction of endogenous arterial GLP-1 concentrations. Insulin and glucagon output from the perfused pancreas are expressed as percentages of basal secretion, which is defined as $100 \%$.

Statistical analysis. Data are expressed as means \pm SEM, and were analysed using GraphPAD InStat software, version 1.13 (San Diego, Calif, USA). In vitro data were analysed using one-sample $t$-tests, analysis of variance (ANOVA) and 2-tailed $t$-tests with correction for multiple comparisons as appropriate. In vivo data were analysed using repeated measures ANOVA and 2-tailed $t$-tests for paired or unpaired data as appropriate. Values of $p$ less than 0.05 were considered to be significant.

\section{Results}

Analogue cross-reactivity. All analogues cross-reacted more than $80 \%$ with the appropriate C-terminal RIA; however, the cross-reactivity with the N-terminally directed 93242 assay varied considerably $\left(\mathrm{Aib}^{8}\right.$ GLP-1, <5\%; Gly ${ }^{8}$-GLP, $17 \%$; Ser $^{8}$-GLP-1, $21 \%$; $\mathrm{Thr}^{8}$-GLP-1, $34 \%$ ). In practice, this meant that C-terminal assays (with appropriate standard) could be used for each analogue (detection limit, $5 \mathrm{pmol} / \mathrm{l}$ ), but N-terminal immunoreactivity, using the appropriate analogue as standard, could be measured for only three analogues $\left(\mathrm{Gly}^{8}{ }^{-}\right.$GLP, $\mathrm{Ser}^{8}{ }^{8}$ GLP-1 and $\mathrm{Thr}^{8}{ }^{8}$ GLP-1; detection limit, 20 pmol/l).

Peptide stability in porcine plasma in vitro. GLP-1 (736) amide was degraded by porcine plasma in vitro at $37^{\circ} \mathrm{C}$, with a $\mathrm{t}_{1 / 2}$ of $28.1 \pm 1.2 \mathrm{~min}(n=12)$. HPLC analysis revealed the time-dependent generation of a second peak corresponding to GLP-1 (9-36) amide, and no other immunoreactive peaks were detected. Incubation of the GLP-1 analogues revealed a significantly $(p<0.0001)$ prolonged $\mathrm{t}_{1 / 2}$ compared to GLP1 (7-36) amide itself (Gly ${ }^{8}$ GLP-1, $159 \pm 12 \mathrm{~min}$, $n=3$; Ser $^{8}$-GLP-1, $174 \pm 12 \mathrm{~min}, n=9$; Thr $^{8}$-GLP-1, $197 \pm 14 \mathrm{~min}, \quad n=3$ ), and again, HPLC analysis showed the formation of only one other peak, in addition to the intact peptide. Degradation of $\mathrm{Aib}^{8}$-GLP$1(n=9)$ was undetectable after $6 \mathrm{~h}$.

Peptide pharmacokinetics in vivo. Stable arterial peptide concentrations were reached after $20 \mathrm{~min}$ of infusion. In all groups, concentrations determined by the C-terminal RIA (which measures both intact and Nterminally degraded peptide) exceeded those determined by the $\mathrm{N}$-terminal assay (illustrated for $\mathrm{Thr}^{8}$ analogue group in Figure 1), while the ratio of N-terminal to C-terminal immunoreactivity was greater for each analogue than for GLP-1 (7-36) amide (Table 1). HPLC analysis of plasma pooled from each group during each infusion revealed two immunoreactive peaks, corresponding to the intact peptide and the N-terminally truncated metabolite. In each 

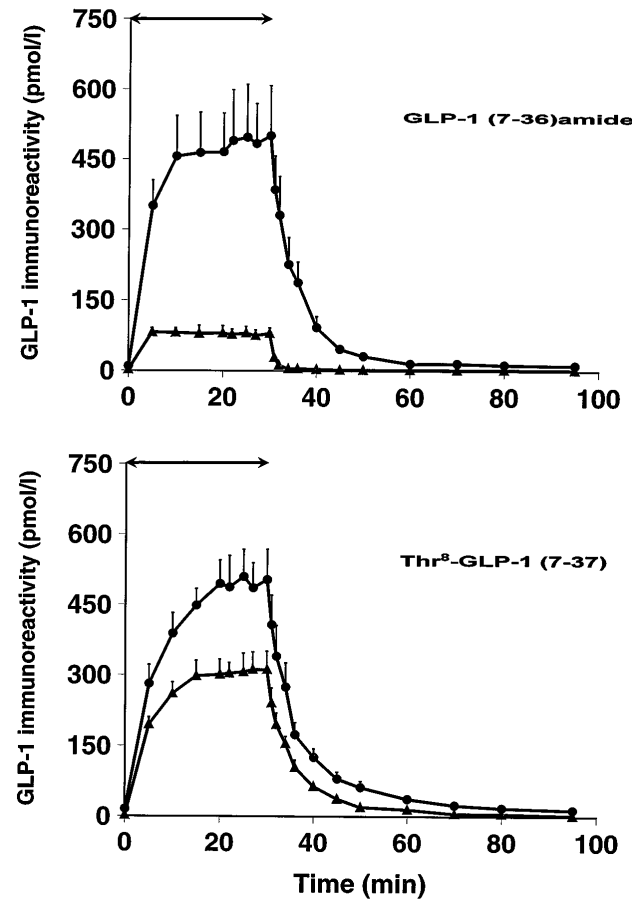

Fig. 1. Plasma GLP-1 immunoreactivity in the carotid artery, measured with C-terminally ( $\bullet$ ) and N-terminally ( $\boldsymbol{\Delta}$ ) directed RIAs. Anaesthetised pigs received separate i.v. infusions $\left(5 \mathrm{pmol} \cdot \mathrm{kg}^{-1} \cdot \mathrm{min}^{-1}\right)$ of GLP-1 (7-36) amide and $\mathrm{Thr}^{8}$ GLP-1 (7-37) in a cross-over design with $80 \mathrm{~min}$ between each infusion. Data are mean $\pm \mathrm{SEM} ; n=4$. The horizontal arrow indicates the period of the infusion

group, a greater percentage of the analogue remained undegraded compared to GLP-1 (7-36) amide (Table 1).

For all four groups, there was no significant difference between the C-terminal $t_{1 / 2}$ for GLP-1 (736) amide or the analogues, but the $\mathrm{N}$-terminal $\mathrm{t}_{1 / 2}$ for each analogue was significantly prolonged (Table 2). For all four groups, the $\mathrm{N}$-terminal $\mathrm{t}_{1 / 2}$ was shorter than the C-terminal $t_{1 / 2}$ for GLP-1 (736) amide, but there was no significant difference be-

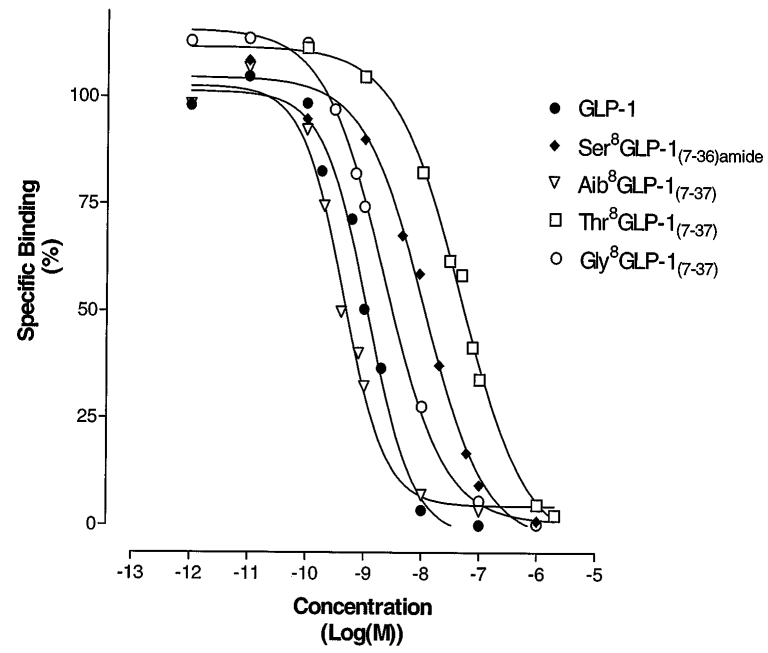

Fig. 2. Binding affinity of GLP-1 analogues using the cloned human GLP-1 receptor. Individual curves are from one representative experiment where the data points are expressed as the mean of duplicate samples

tween $\mathrm{N}$ - and $\mathrm{C}$-terminal $\mathrm{t}_{1 / 2}$ for the analogues (Table 2).

Receptor binding. All the analogues bound to the cloned human pancreatic GLP-1 receptor (Fig.2), but with widely differing binding affinities $\left(\mathrm{IC}_{50}\right.$; Table 3). The $\mathrm{Aib}^{8}$ and Gly ${ }^{8}$ analogues had similar affinities compared to GLP-1 (7-36) amide, while the other two analogues had lower receptor affinities than GLP-1 (7-36) amide.

Isolated perfused pancreas. Perfusion of the pancreas with $1 \mathrm{nmol} / \mathrm{l} \mathrm{GLP}-1$ (7-36) amide or the analogues increased insulin and decreased glucagon release relative to basal secretion (Fig.3). Of the analogues, Aib $^{8}$-GLP-1 (7-36) amide was at least as potent as GLP-1 (7-36) amide in stimulating insulin and inhibiting glucagon secretion, and was significantly $(p<0.05)$ more potent than the $\mathrm{Ser}^{8}$ and $\mathrm{Thr}^{8}$ ana-

Table 1. Plasma concentrations of GLP-1 peptides attained during infusion of GLP-1 (7-36) amide and N-terminally modified analogues calculated using $\mathrm{N}$ - and C-terminally directed RIAs

\begin{tabular}{|c|c|c|c|c|}
\hline \multirow[t]{2}{*}{ Infusion } & \multicolumn{2}{|c|}{ Plateau concentrations (pmol/l) } & \multirow{2}{*}{$\begin{array}{l}\text { N-terminal/C-terminal } \\
\text { immunoreactivity }\end{array}$} & \multirow{2}{*}{$\begin{array}{l}\% \text { intact peptide } \\
\text { after HPLC }\end{array}$} \\
\hline & N-terminal & C-terminal & & \\
\hline $\begin{array}{l}\text { GLP-1 (7-36) amide } \\
\text { Thr }{ }^{8} \text {-GLP-1 (7-37) }\end{array}$ & $\begin{array}{r}76.0 \pm 12.2^{\mathrm{a}} \\
437.8 \pm 49.1^{\mathrm{a}}\end{array}$ & $\begin{array}{l}484.3 \pm 103.1 \\
689.3 \pm 84.4\end{array}$ & $\begin{array}{l}16.4 \pm 1.6^{c} \\
62.2 \pm 0.6\end{array}$ & $\begin{array}{l}24.9 \\
62.5\end{array}$ \\
\hline $\begin{array}{l}\text { GLP-1 (7-36) amide } \\
\text { Gly }- \text {-GLP-1 (7-37) }\end{array}$ & $\begin{array}{l}108.0 \pm 8.6^{\mathrm{a}} \\
336.0 \pm 10.4^{\mathrm{a}}\end{array}$ & $\begin{array}{l}500.3 \pm 67.7 \\
627.0 \pm 24.0\end{array}$ & $\begin{array}{l}22.4 \pm 2.1^{\mathrm{c}} \\
53.8 \pm 2.4\end{array}$ & $\begin{array}{l}23.8 \\
\text { ND }\end{array}$ \\
\hline $\begin{array}{l}\text { GLP-1 (7-36) amide } \\
\text { Ser-GLP-1 (7-36) amide }\end{array}$ & $\begin{array}{l}104.7 \pm 22.8^{\mathrm{a}} \\
331.0 \pm 59.7^{\mathrm{b}}\end{array}$ & $\begin{array}{l}387.0 \pm 59.5 \\
629.7 \pm 137.1\end{array}$ & $\begin{array}{l}26.4 \pm 2.1^{\mathrm{c}} \\
55.7 \pm 3.9\end{array}$ & $\begin{array}{l}24.8 \\
52.2\end{array}$ \\
\hline $\begin{array}{l}\text { GLP-1 (7-36) amide } \\
\text { Aib }^{8}-\text { GLP-1 (7-36) amide }\end{array}$ & $\begin{array}{l}80.3 \pm 7.4^{\mathrm{a}} \\
\text { NDL }\end{array}$ & $\begin{array}{l}267.8 \pm 22.6 \\
530.3 \pm 16.2\end{array}$ & $\begin{array}{l}31.7 \pm 2.1 \\
\text { NDL }\end{array}$ & $\begin{array}{l}17.2 \\
67.1\end{array}$ \\
\hline
\end{tabular}

Values are mean \pm SEM; $n=4$, except for the $\%$ intact peptide after HPLC, which was calculated after HPLC analysis of a single sample of plasma pooled from four animals.
${ }^{\mathrm{a}} p<0.05$ vs C-terminal concentration; ${ }^{\mathrm{b}} \mathrm{NS}, p>0.05$ vs C-terminal concentration; ${ }^{c} p<0.005$ vs analogue; ND, not determined; NDL, not determined due to lack of cross-reactivity 
Table 2. In vivo plasma $\mathrm{t}_{1 / 2}$ for GLP-1 (7-36) amide and N-terminally modified analogues calculated using N-and C-terminally directed RIAs

\begin{tabular}{|c|c|c|c|c|}
\hline \multirow[t]{2}{*}{ Group } & \multicolumn{2}{|c|}{ Analogue $t_{1 / 2}(\min )$} & \multicolumn{2}{|c|}{ GLP-1 (7-36) amide $t_{1 / 2}(\min )$} \\
\hline & $\mathrm{N}$-terminal & C-terminal & N-terminal & C-terminal \\
\hline Thr ${ }^{8}$-GLP-1 (7-37) & $3.9 \pm 0.2^{\mathrm{ab}}$ & $4.2 \pm 0.4^{\mathrm{c}}$ & $0.7 \pm 0.05^{\mathrm{d}}$ & $4.0 \pm 0.1$ \\
\hline Gly ${ }^{8}$-GLP-1 (7-37) & $3.3 \pm 0.4^{\mathrm{ab}}$ & $3.5 \pm 0.7^{\mathrm{c}}$ & $0.9 \pm 0.03^{\mathrm{d}}$ & $4.3 \pm 0.5$ \\
\hline Ser - -GLP-1 (7-36) amide & $3.7 \pm 0.4^{\mathrm{ab}}$ & $4.2 \pm 0.2^{\mathrm{c}}$ & $0.9 \pm 0.06^{\mathrm{d}}$ & $4.1 \pm 0.2$ \\
\hline Aib $^{8}$-GLP-1 (7-36) amide & NDL & $4.4 \pm 0.2^{c}$ & $1.1 \pm 0.07^{\mathrm{d}}$ & $4.3 \pm 0.3$ \\
\hline
\end{tabular}

Values are mean \pm SEM; $n=4$

${ }^{\mathrm{a}} \mathrm{NS}, p>0.05$ vs C-terminal $\mathrm{t}_{1 / 2}$ for analogue; ${ }^{\mathrm{b}} p<0.01$ vs $\mathrm{N}$ terminal $\mathrm{t}_{1 / 2}$ for GLP-1 (7-36) amide; ${ }^{\mathrm{c}} \mathrm{NS}, p>0.05$ vs C-termi-

Table 3. Receptor binding affinities of GLP-1 (7-36) amide and N-terminally modified analogues in baby hamster kidney cells expressing the human pancreatic GLP-1 receptor

\begin{tabular}{lcc}
\hline Peptide & $\begin{array}{l}\text { Binding affinity } \\
\left(\mathrm{IC}_{50}, \mathrm{nmol} / \mathrm{l}\right)\end{array}$ & $n$ \\
\hline GLP-1 (7-36) amide & $0.78 \pm 0.29$ & 8 \\
Thr $^{8}$-GLP-1 (7-37) & $49 \pm 3.7^{\mathrm{a}}$ & 4 \\
Gly $^{8}$-GLP-1 (7-37) & $2.8 \pm 0.42^{\mathrm{b}}$ & 4 \\
Ser $^{8}$-GLP-1 (7-36) amide & $9.0 \pm 1.9^{\mathrm{a}}$ & 3 \\
Aib $^{8}$-GLP-1 (7-37) & $0.45 \pm 0.05^{\mathrm{b}}$ & 3 \\
\hline
\end{tabular}

Values are mean \pm SD of separate triplicate experiments. ${ }^{\mathrm{a}} p<0.001$ vs GLP-1 (7-36) amide; ${ }^{\mathrm{b}} \mathrm{NS}, p>0.05$ vs GLP-1 (736) amide

logues in raising insulin output. It was also the most potent $(p<0.05)$ of all the analogues in reducing glucagon output. The Gly ${ }^{8}$ analogue was not significantly different to GLP-1 (7-36) amide in stimulating insulin or inhibiting glucagon secretion, but was more potent $(p<0.05)$ than the $\operatorname{Ser}^{8}$ and $\mathrm{Thr}^{8}$ analogues in inhibiting glucagon release, while the $\mathrm{Thr}^{8}$ analogue was the least potent of the analogues tested.

\section{Discussion}

This study has demonstrated that small alterations in the N-terminus of GLP-1 confer resistance to the action of the enzyme DPP IV. Such analogues retain biological activity, and have an improved metabolic stability.

In incubations with human plasma in vitro, DPP IV is the main enzyme responsible for GLP-1 degradation $[12,13]$, and a thorough study by Pauly et al. [31] concluded that only minor secondary degradation could be attributed to other serum proteases. Accordingly, the in vitro $t_{1 / 2}$ of the GLP-1 analogues were considerably extended relative to GLP-1 (736) amide. There was no detectable degradation of the $\mathrm{Aib}^{8}$ analogue, and the slow degradation of the other three analogues could reflect the substrate specificity of DPP IV, as was found for GRF; substitution of the alanine in position 2 of modified GRF analogues with either serine or threonine reduced the nal $\mathrm{t}_{1 / 2}$ for GLP-1 (7-36) amide; ${ }^{\mathrm{d}} p<0.01$ vs C-terminal $\mathrm{t}_{1 / 2}$ for GLP-1 (7-36) amide; NDL, not determined due to lack of cross-reactivity

\section{Insulin}
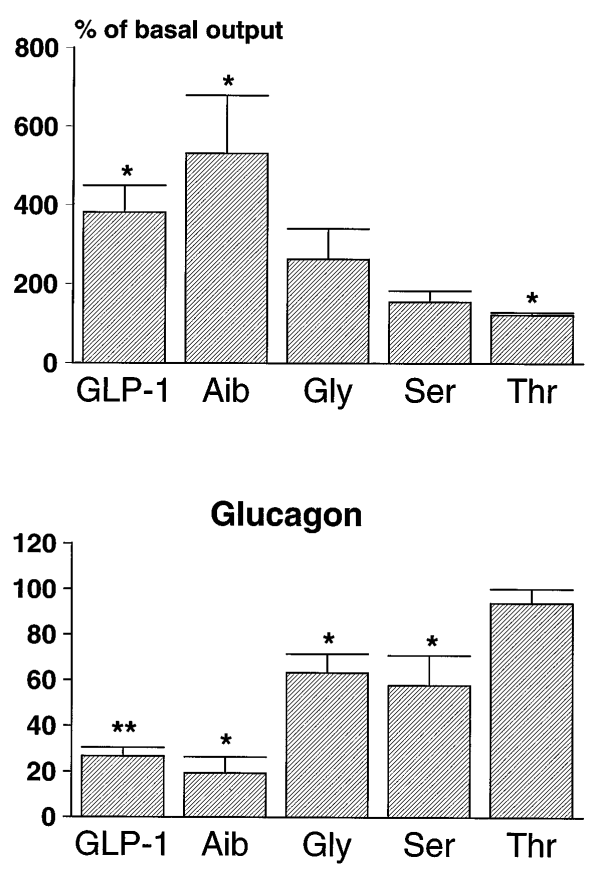

Fig.3. Insulin and glucagon secretion by the isolated perfused porcine pancreas during infusion of $1 \mathrm{nmol} / 1$ GLP-1 (736) amide or N-terminally modified analogues. Data are expressed as a percentage of basal output (defined as $100 \%$ ), and are mean \pm SEM of 4 experiments, except for the glucagon output during GLP-1 (7-36) amide infusion where $n=3$.

$* p<0.05 ; * * p<0.01$ compared to basal output

cleavage rates to less than $5 \%$, of that of the $\mathrm{Ala}^{2}$ analogue [20]. That DPP IV is also the main enzyme responsible for in vivo N-terminal degradation of GLP1 is illustrated by the increased proportions of N-terminal immunoreactivity (reflecting intact peptide) seen during i.v. infusion of each analogue relative to GLP-1 itself, and confirmed by HPLC analysis which revealed only two immunoreactive peaks corresponding to the intact peptide and the N-terminally truncated metabolite. In these in vivo studies, analogue $\mathrm{N}$-terminal $\mathrm{t}_{1 / 2}$ were prolonged and equalled the C-terminal $\mathrm{t}_{1 / 2}$, but it is noteworthy that they could not be extended beyond those determined by 
the C-terminal assay, presumably due to the presence of other, non-DPP IV-mediated degradation pathways which become relevant in the intact animal. In studies of GLP-1 metabolism in the rat [14], dog [16, 32] and pig [33], N-terminal degradation was shown to be particularly important, but the involvement of other enzymes was also indicated. Renal metabolism leading to substantial degradation to small, undetectable fragments or complete cleavage was indicated to be a major route of GLP-1 elimination [33], and may explain why no other metabolites were detected after HPLC analysis in the present study.

The binding affinity $\left(\mathrm{IC}_{50}\right)$ for GLP-1 in the present study correlates well with the previously published $\mathrm{K}_{\mathrm{d}}$ of $0.5 \mathrm{nmol} / \mathrm{l}$ [34]. All four analogues also bound to the cloned GLP-1 receptor, with the $\mathrm{Aib}^{8}$ and Gly ${ }^{8}$ analogues having similar affinities to GLP1 itself. It may be that, for the other analogues, steric hindrances cause the reduction in binding affinity, with the polar hydroxyl group in the serine and threonine residues impairing binding due to spatial constraints.

In the isolated perfused pancreas, all the GLP-1 analogues were, to varying extents, capable of releasing insulin and/or inhibiting glucagon secretion, with potency orders reflecting receptor affinities. Similar findings were seen for GRF; serine, threonine and glycine substituted analogues were stabilised against proteolysis in plasma, but had low inherent growth hormone releasing activity when tested in vitro [35]. However, the potency order in vivo changed, with the $\mathrm{Thr}^{2}$ analogue becoming more potent than native GRF, which may be explained by the improved metabolic stability of the analogue in vivo compensating for its lower in vitro potency.

GLP-1 has been suggested to be a useful new therapy in the treatment of NIDDM [6, 8-11]. However, the therapeutic potential of native GLP-1 is limited by its susceptibility to degradation by DPP IV [1214], with the concomitant formation of a metabolite which may act as an antagonist in its own right $[15$, 16]. The short metabolic stability of the intact peptide can be offset by sustained i.v. infusion or by development of a protracted formulation, but this does not overcome the effect of DPP IV action. In recent studies in patients with NIDDM in whom GLP-1 was infused overnight, Rachman et al. [36, 37] observed that, despite an initial fall, blood glucose concentrations gradually increased during the night, although they remained lower than in the saline-treated group. These authors concluded that "GLP-1 may have been losing its efficacy overnight". Another explanation could be that concentrations of GLP1 (9-36) amide increase during the overnight GLP-1 infusion, so that the gradual rise in blood glucose may not be due to a post-receptor down-regulation, but rather to a local accumulation of metabolite antagonising the action of the residual intact peptide.
In these studies [36, 37], the relative concentrations of intact GLP-1 and metabolite were not assessed, but this was addressed in another study, where GLP1 (9-36) amide was found to reach $80 \%$ of the total plasma immunoreactivity during an i. v. infusion of GLP-1 in NIDDM and control subjects [17]. However, marked desensitisation appears not to occur, since when GLP-1 was infused in NIDDM patients continuously i. v. over a 7-day period, both fasting and postprandial glucose levels were significantly lower on the 7th day of treatment compared to pre-treatment values [38]. This study [38] was the first to show that continuous GLP-1 infusion is capable of improving glycaemic control in NIDDM patients for a prolonged period, although it should be borne in mind that neither this [38] nor any other study has unequivocally excluded the possibility that some loss of efficacy occurs over the course of the treatment period.

It appears that in order to maintain its effect, GLP-1 must be continuously present. Thus, in NIDDM patients, when the peptide was infused for only $16 \mathrm{~h}$ instead of continuously over $24 \mathrm{~h}$, the beneficial effect on fasting blood glucose was reduced [39]. Similar results are seen when GLP-1 is given to NIDDM patients as repeated s.c. injections. When administered 3 times daily before meals, it retained its ability to reduce postprandial increases in blood glucose throughout the 1 week course of the study [40], but the effect was lost between meals, suggesting that GLP-1 concentrations fell below the threshold for activity between successive injections. An earlier study be the same group [41] followed the kinetics, and showed that total GLP-1 immunoreactivity returned to basal levels by $215 \mathrm{~min}$ after the peptide injection. Similar findings were reported when immunoreactive GLP-1 was characterised by HPLC after s. c. administration to diabetic and non-diabetic subjects [17]. By $30 \mathrm{~min}$ after administration, the metabolite accounted for around $80 \%$ of the plasma immunoreactivity, and concentrations of both GLP1 (7-36) amide and GLP-1 (9-36) amide returned to basal values within $4 \mathrm{~h}$. The effect of repeated s.c. injections of GLP-1 given before meals was confirmed in another study using poorly controlled NIDDM patients on sulphonylurea therapy [42]. Here, the peptide maintained its beneficial effect on postprandial glucose levels over the 3-week study period, although, again, it had no effect on fasting glucose levels. Thus, it appears that when GLP-1 is given as repeated injections before meals, full $24 \mathrm{~h}$ control of blood glucose is not attained. Tachyphylaxis appears not to occur, possibly because both intact peptide and the metabolite are eliminated between successive injections, preventing accumulation of a potential antagonist, however, leaving a period when there is insufficient intact GLP-1 left to maintain an effect. 
The kinetic data reported here for the GLP-1 analogues indicate that resistance to degradation by DPP IV is associated with prolonged metabolic stability in vivo, raising the possibility that such analogues may have greater potency and duration of action. Clearly, further dynamic studies in vivo are required to test whether this hypothesis is valid, and to see whether the 3 -fold improvement in plasma $t_{1 / 2}$ of the analogues in itself is sufficient to maintain an effect or requires development of a protracted formulation. Nonetheless, DPP IV-resistant analogues may be one method of realising GLP-1's potential in diabetes therapy, by extending its duration of action while, at the same time, minimising the build up of undesirable metabolites.

Acknowledgements. This work was supported by grants from the Danish Medical Research Council and the Danish Biotechnology Programme. The technical assistance of Letty Klarskov, Mette Olesen and Mette Frost is gratefully acknowledged. Siv Hjort is thanked for kindly providing the pAH 260 vector.

\section{References}

1. Holst JJ (1983) Gut glucagon, enteroglucagon, gut glucagonlike immunoreactivity, glicentin: current status. Gastroenterology 84: 1602-1613

2. Ørskov C (1992) Glucagon-like peptide-1, a new hormone of the entero-insular axis. Diabetologia 35: 701-711

3. Ørskov C, Rabenhøj L, Wettergren A, Kofod H, Holst JJ (1994) Tissue and plasma concentrations of amidated and glycine-extended glucagon-like peptide-1 in humans. Diabetes 43: 535-539

4. Ørskov C, Holst JJ, Nielsen OV (1988) Effect of truncated glucagon-like peptide-1 [proglucagon-(78-107) amide] on endocrine secretion from pig pancreas, antrum and non-antral stomach. Endocrinology 123: 2009-2013

5. Kreymann B, Williams G, Ghatei MA, Bloom SR (1987) Glucagon-like peptide 17-36: a physiological incretin in man. Lancet ii: 1300-1304

6. Nathan DM, Schreiber E, Fogel H, Mojsov S, Habener JF (1992) Insulinotropic action of glucagonlike peptide-I-(7$37)$ in diabetic and nondiabetic subjects. Diabetes Care 15: 270-276

7. Weir GC, Mojsov S, Hendrick GK, Habener JF (1989) Glucagon-like peptide 1 (7-37) actions on endocrine pancreas. Diabetes 38: 338-342

8. Gutniak M, Ørskov C, Holst JJ, Ahrén B, Efendic S (1992) Anti-diabetogenic effect of glucagon-like peptide-1 (736) amide in normal subjects and patients with diabetes mellitus. N Engl J Med 326: 1316-1322

9. Nauck MA, Heimsaat MM, Ørskov C, Holst JJ, Ebert R, Creutzfeldt W (1993) Preserved incretin activity of glucagon-like peptide-1 [7-36 amide] but not of synthetic gastric inhibitory polypeptide in patients with type-2 diabetes mellitus. J Clin Invest 91: 301-307

10. Holz GG, Kühtreiber WM, Habener JF (1993) Pancreatic beta cells are rendered glucose-competent by the insulinotropic hormone glucagon-like peptide-1 (7-36). Nature 361: 362-365

11. Thorens B, Waeber G (1993) Glucagon-like peptide-1 and the control of insulin secretion in the normal state and in NIDDM. Diabetes 42: 1219-1225
12. Mentlein R, Gallwitz B, Schmidt WE (1993) Dipeptidyl peptidase IV hydrolyses gastric inhibitory polypeptide, glucagon-like peptide-1 (7-36) amide, peptide histidine methionine and is responsible for their degradation in human serum. Eur J Biochem 214: 829-835

13. Deacon CF, Johnsen AH, Holst JJ (1995) Degradation of glucagon-like peptide-1 by human plasma in vitro yields an N-terminally truncated peptide which is a major endogenous metabolite in vivo. J Clin Endocrinol Metab 80: 952-957

14. Kieffer TJ, McIntosh CHS, Pederson RA (1995) Degradation of glucose-dependent insulinotropic polypeptide (GIP) and truncated glucagon-like peptide 1 (tGLP-1) in vitro and in vivo by dipeptidyl peptidase IV. Endocrinology 136: 3585-3596

15. Grandt B, Sieburg B, Sievert J et al. (1994) Is GLP-1 (936) amide an endogenous antagonist at GLP-1 receptors? Digestion 55: 302A (Abstract)

16. Knudsen LB, Pridal L (1996) Glucagon-like peptide-1 (936) amide is a major metabolite of glucagon-like peptide-1 (7-36) amide after in vivo administration to dogs, and it acts as an antagonist on the pancreatic receptor. Eur J Pharmacol 318: 429-435

17. Deacon CF, Nauck MA, Toft-Nielsen M, Pridal L, Willms B, Holst JJ (1995) Both subcutaneously and intravenously administered glucagon-like peptide-1 are rapidly degraded from the $\mathrm{NH}_{2}$-terminus in type II diabetic patients and in healthy subjects. Diabetes 44: 1126-1131

18. Heins J, Neubert K, Barth A, Canizaro PC, Behal FJ (1984) Kinetic investigation of the hydrolysis of aminoacyl p-nitroanilides by dipeptidyl peptidase IV from human and pig kidney. Biochim Biophys Acta 785: 30-35

19. Rahfeld J, Schutkowski M, Faust J, Neubert K, Barth A, Heins J (1991) Extended investigation of the substrate specificity of dipeptidyl peptidase IV from pig kidney. Biol Chem Hoppe-Seyler 372: 313-318

20. Martin RA, Cleary DL, Guido DM, Zurcher- Neely HA, Kubiak TM (1993) Dipeptidyl peptidase IV (DPP IV) from pig kidney cleaves analogs of bovine growth hormone-releasing factor (bGRF) modified at position 2 with Ser, Thr or Val. Extended DPP-IV substrate specificity? Biochim Biophys Acta 1164: 252-260

21. Southern PJ, Berg P (1982) Transformation of mammalian cells to antibiotic resistance with a bacterial gene under the control of the SV40 early region promoter. J Mol Appl Genet 1: 327-341

22. Chen C, Okayama H (1987) High-efficiency transformation of mammalian cells by plasmid DNA. Mol Cell Biol 7: 2745-2752

23. Thorell JI, Johansson BG (1971) Enzymatic iodination of polypeptides with ${ }^{125}$ I to high specific activity. Biochim Biophys Acta 251: 363-369

24. Drejer K, Kruse V, Larsen UD, Hougaard P, Bjørn S, Gammeltoft S (1991) Receptor binding and tyrosine kinase activation by insulin analogues with extreme affinities studied in human hepatoma HepG2 cells. Diabetes 40: 1488-1495

25. Holst JJ, Fahrenkrug J, Knuhtsen SL, Poulsen SS, Nielsen OV (1984) Vasoactive intestinal polypeptide (VIP) in pig pancreas: role of VIPergic nerves in control of fluid and bicarbonate secretion. Regul Pept 8: 245-259

26. Ørskov C, Holst JJ, Seier Poulsen S, Kirkegaard P (1987) Pancreatic and intestinal processing of proglucagon in man. Diabetologia 30: 874-881

27. Ørskov C, Jeppesen J, Madsbad S, Holst JJ (1991) Proglucagon products in the plasma of non-insulin dependent diabetics and nondiabetic controls in the fasting state and fol- 
lowing oral glucose and intravenous arginine. J Clin Invest 87: $415-423$

28. Gutniak MK, Larsson H, Heiber SJ, Juneskans OT, Holst JJ, Ahrén B (1996) Potential therapeutic levels of glucagon-like peptide I achieved in humans by a buccal tablet. Diabetes Care 19: 843-848

29. Hvidberg A, Nielsen MT, Hilstead J, Ørskov C, Holst JJ (1994) Effect of glucagon-like peptide-1 (proglucagon 78107 amide) on hepatic glucose production in healthy man. Metab Clin Exp 43: 104-108

30. Holst JJ (1980) Evidence that glicentin contains the entire sequence of glucagon. Biochem J 187: 337-343

31. Pauly RP, Rosche F, Wermann M, McIntosh CH, Pederson RA, Demuth HU (1996) Investigation of glucose-dependent insulinotropic polypeptide-(1-42) and glucagon-like peptide-1-(7-36) degradation in vitro by dipeptidyl peptidase IV using matrix-assisted laser desorption/ionizationtime of flight mass spectrometry. A novel kinetic approach. J Biol Chem 271: 23222-23229

32. Pridal L, Deacon CF, Kirk O, Christensen JV, Carr RD, Holst JJ (1996) Glucagon-like peptide-1 (7-37) has a larger volume of distribution than glucagon-like peptide-1 (736) amide in dogs and is degraded more quickly in vitro by dog plasma. Eur J Drug Metab Pharmacokinet 21: 51-59

33. Deacon CF, Pridal L, Klarskov L, Olesen M, Holst JJ (1996) Glucagon-like peptide 1 undergoes differential tissue-specific metabolism in the anesthetized pig. Amer J Physiol 271: E458-E464

34. Thorens B, Porret A, Bühler L, Deng S-P, Morel P, Widmann C (1993) Cloning and functional expression of the human islet GLP-1 receptor. Demonstration that exendin4 is an agonist and exendin-(9-39) an antagonist of the receptor. Diabetes 42: 1678-1682
35. Kubiak TM, Friedman AR, Martin RA et al. (1993) Position 2 and position 2/Ala 15-substituted analogs of bovine growth hormone-releasing factor (bGRF) with enhanced metabolic stability and improved in vivo bioactivity. J Med Chem 36: 888-897

36. Rachman J, Gribble FM, Barrow BA, Levy JC, Buchanan KD, Turner RC (1996) Normalization of insulin responses to glucose by overnight infusion of glucagon-like peptide 1 (7-36) amide in patients with NIDDM. Diabetes 45: 15241530

37. Rachman J, Barrow BA, Levy JC, Turner RC (1997) Nearnormalisation of diurnal glucose concentrations by continuous administration of glucagon-like peptide-1 (GLP-1) in subjects with NIDDM. Diabetologia 40: 205-211

38. Larsen J, Jallad N, Damsbo P (1996) One-week continuous infusion of GLP-1 (7-37) improves the glycaemic control in NIDDM. Diabetes 45 [Suppl 2]: 233A (Abstract)

39. Larsen J, Damsbo P (1997) GLP-1 must be present continuously in order to obtain good glycaemic control in NIDDM. Diabetes 46 [Suppl 1]: 186A (Abstract)

40. Juntti-Berggren L, Pigon J, Karpe F et al. (1996) The antidiabetogenic effect of GLP-1 is maintained during a 7-day treatment period and improves diabetic dyslipoproteinemia in NIDDM patients. Diabetes Care 19: 1200-1206

41. Gutniak MK, Linde B, Holst JJ, Efendic S (1994) Subcutaneous injection of the incretin hormone glucagon-like peptide 1 abolishes postprandial glycemia in NIDDM. Diabetes Care 17: 1039-1044

42. Todd JF, Wilding JPH, Edwards CMB, Khan FA, Ghatei MA, Bloom SR (1997) Glucagon like peptide 1 (GLP-1): a trial of treatment in noninsulin dependent diabetes mellitus. Eur J Clin Invest 27: 533-536 